\title{
Fractionation of carbohydrates and proteins and in vitro rumen kinetics of corn silage under various storage durations
}

\author{
S. Naetzold"1 ${ }^{\# 1}$ J. Viégas ${ }^{1}$, F.R. Skonieski ${ }^{2}$, T.J. Tonin ${ }^{1}$, L.L. Schumacher ${ }^{1}$, M.B. Fagundes ${ }^{3}$, \\ L.T. Rocha ${ }^{1}$, \& R. Wagner ${ }^{3}$ \\ ${ }^{1}$ Federal University of Santa Maria, Animal Science Postgraduate Program, Rio Grande do Sul, Santa Maria, Brazil \\ ${ }^{2}$ Federal Technological University of Paraná, Dois Vizinhos, Paraná, Brazil \\ ${ }^{3}$ Federal University of Santa Maria, Food Technology Graduate Program, Rio Grande do Sul, Santa Maria, Brazil
}

(Received 19 August 2020; Accepted 8 May 2021; Published 26 August 2021)

\begin{abstract}
Copyright resides with the authors in terms of the Creative Commons Attribution 4.0 South African Licence.
See: http://creativecommons.org/licenses/by/4.0/za

Condition of use: The user may copy, distribute, transmit and adapt the work, but must recognise the authors and the South African Journal of Animal Science.
\end{abstract}

\begin{abstract}
The experiment evaluated the effects on the chemical composition (fermentation, kinetic parameters, and protein and carbohydrate fractions) of corn silage after various storage durations $(45,90,180$, and 360 days). Experimental mini silos of the corn plants were made and opened after various storage periods. The experimental design was completely randomized with four treatments and four replications per treatment. Variables such as $\mathrm{pH}$, lactic acid and acetic acid showed a quadratic effect, whereas effluent and gas losses increased linearly with prolonged storage. Proteolysis was observed with an increase in storage, resulting in a rise in ammonia- $\mathrm{N}$, soluble $\mathrm{N}$, and non-protein $\mathrm{N}$ concentration and reduction in true protein. The soluble carbohydrate fractions were reduced, and digestible and indigestible fibre were increased. For the kinetic degradation parameters of the silages obtained through in vitro gas methodology, the highest fermentation rate occurred in the first 12 hours of incubation, and the highest volume of gas produced within 96 hours was obtained for silages with shorter storage ( 45 days). The increase in storage resulted in greater losses and lower ruminal degradability in vitro, causing a decrease in protein quality and nutritional value.
\end{abstract}

Keywords: fermentation, gas production, nitrogen fraction

\#Correspondence: snaetzold@gmail.com

\section{Introduction}

Corn silage has low buffering capacity and adequate levels of soluble carbohydrates that stimulate the growth and development of lactic acid-producing bacteria (Kung Jr et al., 2018), which allows a marked reduction in $\mathrm{pH}$ during the initial phase of the fermentation process. Maize silages, as a major part of ruminant rations, are usually stored anaerobically for 1 to 12 months before being fed. A stable phase of the ensiling process was reported in literature (Pahlow et al., 2003), meaning that most active metabolic processes in silos ceased within two to six weeks of fermentation. However, studies have shown that certain chemical components and fermentative parameters of silages change even after the onset of the stable phase (Der Bedrosian et al., 2012; Arcari et al., 2016).

Other processes also appear to continue after active fermentation ceases, as reported by Hoffman et al. (2011) and Ferraretto et al. (2015), who evaluated corn silage with storage of up to 240 days. In both studies, they observed that ammonia- $\mathrm{N}$ and soluble $\mathrm{N}$ increased with storage time. Although not fermented directly by lactic acid bacteria, fibrous fractions of silages can be altered with increased storage, according to Der Bedrosian et al. (2012), who observed partial hydrolysis of hemicellulose during ensiling. Hoffman et al. (2011) reported that longer storage contributed to the degradation of proteins such as prolamins, which involve the protein matrix of the grain, thus allowing greater access to starch by ruminal microorganisms. Increasing the silage storage time may be a beneficial strategy for milk producers to increase rumen starch hydrolysis (Kung Jr. et al., 2018).

The in vitro gas production technique has been used widely to evaluate the kinetic degradation of ruminal microbial fermentation processes (LI et al., 2014). This technique is based on the assumption that gas produced from cultures inoculated with mixed microorganisms is directly related to the amount of substrate that is fermented (López et al., 2007). When food is analysed with the vitro gas production 
technique, it is expected that samples that produce more gas would be better used by ruminants, thus being able to increase their production. The application of non-linear models to the quantity of gas produced across time results in the estimation of rates of degradation and volume of gas that is produced from fibrous and non-fibrous carbohydrates and the latency time of the fermentation process (Schofield et al., 1994).

The in vitro gas technique enables accurate prediction of the quality of ensiled material on a large scale. Naeini et al. (2014) demonstrated changes in in vitro digestibility and gas production from sorghum silages stored for a prolonged period. Moreover, evaluating the influence of the length of time corn silage is stored in experimental silos on the fermentation process could provide information about the need for and types of inoculation and additives to be included in corn silages. Therefore, fermentative losses and changes in digestibility and in the chemical and nitrogen composition of the silages may require changes in the formulation of the diet over time. Thus, the objective of this study was to evaluate the effects of storage duration on fermentation, kinetic parameters, and protein and carbohydrate fractions of corn silage.

\section{Materials and Methods}

The experiment was conducted in the city of Santa Maria at latitude 29.71 ' 80 ' $S$ and longitude $53.73^{\prime} 31^{\prime}$ W, with an average height above sea level of $95 \mathrm{~m}$, in the state of Rio Grande do Sul, Brazil, from October 2016 to June 2018. The climate of the region is the Cfa type, that is, humid subtropical (Köppen \& Geiger, 1928). The soil is classified as red dystrophic sandy Acrisol (Embrapa, 2006).

The experimental area of $1500 \mathrm{~m}^{2}$ was sown in October 2016, in rows spaced $0.45 \mathrm{~m}$ apart with 3.6 seeds planted per linear metre. Fertilizer was applied at the time of sowing. Corn plants were harvested at an average soil height of $20 \mathrm{~cm}$ when most of the grains were at the $50 \%$ stage of the milk line, and were fragmented in a shredder with an average particle size of $2 \mathrm{~cm}$.

The treatments consisted of various durations of storage (45, 90, 180, and 360 days after ensiling), with four replications (silos) per treatment. The silages were produced on 8 April 2017, 128 days after cultivation, and the material was ensiled in experimental mini silos, compacted properly, and sealed hermetically in four plastic bags to protect against air ingress and light. The average density of silages was $716 \mathrm{~kg} / \mathrm{m}^{3}$ fresh matter. The silos contained $6 \mathrm{~kg}$ of silage and $2 \mathrm{~kg}$ of sand for effluent recovery. Playne \& McDonald's (1966) methodology was used to evaluate the buffering capacity.

At the time of opening, one sample was collected from each silo to determine the $\mathrm{pH}$ (Silva \& Queiroz, 2002) and another for extraction by pressing the silage liquid (Carver press). These samples were used for the analysis of ammonia- $\mathrm{N}$ in relation to total nitrogen $\left(\mathrm{NH}_{3}-\mathrm{N} / \mathrm{TN}\right)$ using the colorimetry method (Weatherburn, 1967). For volatile fatty acids (VFA), acetic, propionic and butyric acid samples were prepared according to Tangerman and Nagengast (1996), whereas lactic acid was subjected to the derivatization process with the aid of $\mathrm{N}$-tert-butyldimethylsilyl-N-methyltrifluoroacetamide, according to Oms-Oliu et al. (2011). Subsequently, the concentrations of all acids were analysed with a gas chromatograph equipped with a Varian Star $3400 \mathrm{CX}$ flame ionization detector (GC-FID, CA, USA). The separation was performed on a polar capillary column (Chrompack, CP-WAX $52 \mathrm{CB}$, USA) with a $50 \mathrm{~m} \times 0.25 \mathrm{~mm}$ i.d. $\times 0.25 \mu \mathrm{m}$ thick film, using hydrogen as a carrier gas at a constant pressure of 15 psi. However, for lactic acid, the SGE-BPX 5 column was used with a $30 \mathrm{~m} \times 0.22 \mathrm{~mm}$ i.d. $\times 0.25 \mathrm{~mm}$ thick film.

Soluble sugars were determined using the phenol-sulfuric colorimetric method (Hall, 2000). Subsequently, another silage sample was placed in a forced air circulation oven at an average temperature of $55^{\circ} \mathrm{C}$ until it reached a constant and heavy weight to determine the partially dry matter, and then ground in a Wiley mill with a mesh sieve of $1 \mathrm{~mm}$ for chemical analysis. Dry matter (DM) was determined in a kiln at $105{ }^{\circ} \mathrm{C}$ for a minimum of eight hours, and mineral matter was determined by incineration in a muffle furnace at $550{ }^{\circ} \mathrm{C}$ for four hours. Crude protein (CP) determination was performed with the micro-Kjeldahl method (method 960.52, AOAC, 1995) and ether extract (EE) was assessed (method 920.39, AOCS, 2005).

Neutral detergent fibre (NDF) levels were obtained with the use of thermostable $\alpha$-amylase (Termamyl 120 L, Novozimes Latin America, LTDA) and autoclave equipment, according to the technique described by Senger et al. (2008). Acid detergent fibre and lignin contents were obtained according to Van Soest et al. (1991), with lignin being extracted with sulfuric acid $72 \%$. Hemicellulose and cellulose content was obtained by considering the differences between the levels of NDF and ADF and those of ADF and lignin.

Neutral detergent insoluble $\mathrm{N}$ levels, acid detergent insoluble $\mathrm{N}$, soluble $\mathrm{N}$, non-protein $\mathrm{N}$ determination, and the equations used to calculate $\mathrm{N}$ fractionation $(\mathrm{N})$ were analysed as described by Licitra et al. (1996). The fractions are described as follows: $\mathrm{A}=$ non-protein $\mathrm{N} ; \mathrm{B} 1=$ borate phosphate buffer soluble protein, which is precipitated in trichloroacetic acid and is rapidly degradable in the rumen; B2 = borate buffer insoluble protein, which is present in cellular content and at the intermediate degradation stage; $\mathrm{B} 3=$ insoluble protein, which is degrading slowly in the rumen; $\mathrm{C}=$ protein, which is rumen insoluble and indigestible in the gastrointestinal tract. 
Carbohydrate fractionation was performed according to Lanzas et al. (2007). The fractions were divided as $\mathrm{CHO}=$ total carbohydrate, NFC $=$ non-fibrous carbohydrate, $\mathrm{A} 1=$ sum of volatile fatty acids (acetic, propionic, butyric, and isobutyric acids), A2 = lactic acid, A3 = other organic acids, A4 = soluble sugars, B1 = starch, B2 = soluble fibre, B3 = digestible fibre, and C = indigestible fibre.

Starch determination was performed using the method proposed by Walter et al. (2005), which includes sequential enzymatic digestion with amylase (Termamyl) (120 L), amyloglucosidase (300 L), and protease (Flavourzyme) $(500 \mathrm{~L})$ for starch and protein hydrolysis. The sugars that resulted from this digestion were quantified with a spectrophotometer at an absorbance of $\lambda=505 \mathrm{~nm}$, using the glucose oxidase peroxidase kit as the colour reagent.

In vitro ruminal fermentation kinetics analyses were performed according to techniques adapted from Schofield et al. (1994) and Theodorou et al. (1994). Samples $(0.5 \mathrm{~g})$ were weighed in fermentation flasks with capacity of $160 \mathrm{~mL}$. Forty millilitres of culture medium (buffer) and $10 \mathrm{~mL}$ of rumen liquid filtered through two layers of cotton gauze were added under continuous $\mathrm{CO}_{2}$ injection and kept in a water bath at $39^{\circ} \mathrm{C}$. After inoculation of the ruminal liquid, the vials were placed in a water bath at $39^{\circ} \mathrm{C}$ with constant agitation for 96 hours. Gas production was measured at 3, 6, 9, 12, 18, 24, 30, 36, 42, 48, 72, and 96 hours. The calculations of the parameters of gas production kinetics were performed with SAS ${ }^{\circledR}$ university edition version.

The ruminal fluid was collected from two fistulated cattle with $10 \mathrm{~cm}$ cannulas. The use of this technique was approved by the Animal Use Ethics Committee of the Federal University of Santa Maria (CEUA) under protocol number 5439180417. Ruminal fluid collection was performed with a vacuum pump attached to a Kitazato vial. It was kept at a controlled temperature of $39^{\circ} \mathrm{C}$ in a water bath during collection. The animals were adapted to corn silage for ten days before rumen fluid collection.

The gas production data were fit to a logistic regression model (Schofield et al., 1994):

$$
V_{t}=V_{f}(1+\exp (2-4 S(t-L)))^{-1}
$$

where: $V_{f}$ is the final volume of gas $(\mathrm{mL})$ at time $t, S$ is the rate of degradation per hour, and $L$ is the colonization time (hours).

The organic matter digestibility was calculated from the 24-hour gas production (GP) following Menke et al. (1979) as:

$$
O D M=148.8+\left(8.89 G P_{24}\right)+0.45 C P+0.0651 C A
$$

where: $O M D$ is the digestibility of organic matter $(\mathrm{g} / \mathrm{kg} \mathrm{DM})_{2}$

$G P_{24}$ is net gas production ( $\mathrm{ml} / \mathrm{g} \mathrm{OM}$ ) at 24 hours of incubation,

$C P$ is crude protein $(\mathrm{g} / \mathrm{kg} \mathrm{DM})$, and

$C A$ is crude ash $(\mathrm{g} / \mathrm{kg} \mathrm{DM})$.

The experimental design was completely randomized, with four treatments and four replications each. Thus, an analysis of variance was performed to detect differences among times from ensiling to opening using the model:

$$
y_{i j}=\mu+t_{i}+e_{i j}
$$

where: $y_{i j}=$ value observed in the experimental unit receiving treatment $i$ in repetition $j$;

$\mu=$ is the overall effect of the mean,

$t_{i}=$ effect of treatment $i$; and

$e_{i j}=$ random error (residual).

This model was fit to the data treating the treatment effects both as a categorical effect to estimate the means and as a continuous effect to determine the shape (linear or quadratic) of the response surface. Significance was established with the critical value $P<0.05$. SAS software (SAS Institute Inc. Cary, North Carolina, USA) was used for the analyses.

\section{Results and Discussion}

As the period of time for which the silages were stored increased, the DM content of the maize silage decreased and the effluent increased (Table 1). This may be the result of having harvested the crop before it reached a dry matter content of less than $300 \mathrm{~g} / \mathrm{kg}$ (Bueno et al., 2020). Harvesting the crop too soon may have resulted in lower production per area and more intense fermentation. 
Ammonia- $\mathrm{N}$ and soluble $\mathrm{N}$ increased as a function of storage duration, as did the quantities of losses of effluent and gas produced. Because of the increase in ammonia- $\mathrm{N}$ in the medium, and possibly $\mathrm{CO}_{2} / \mathrm{CH}_{4}$, the $\mathrm{pH}$ values rose with storage. Lactic acid had the highest concentration compared with other VFAs.

Lactic acid and acetic acid showed a quadratic behaviour, with maximum concentrations of 41.80 and $19.57 \mathrm{~g} / \mathrm{kg}^{-1}$ at 162 and 233 days of fermentation, respectively. Propionic acid showed an increasing linear behaviour during storage (Table 1). Butyric acid levels did not fit the regression analysis $(P>0.05)$ with a mean value of $0.10 \%$ of $\mathrm{DM}$.

Table 1 Estimates of fermentation parameters for maize silage when stored for various periods after ensiling

\begin{tabular}{|c|c|c|c|c|c|c|c|c|c|}
\hline \multirow[b]{2}{*}{$\begin{array}{l}\text { Variables, } \\
\text { g/kg DM }\end{array}$} & \multicolumn{5}{|c|}{ Storage period of silage } & \multirow[b]{2}{*}{ SE } & \multirow[b]{2}{*}{ Equations } & \multirow[b]{2}{*}{$\mathrm{R}^{2}$} & \multirow[b]{2}{*}{$P$-value } \\
\hline & $\begin{array}{c}\text { Pre- } \\
\text { ensiling }\end{array}$ & 45 & 90 & 180 & 360 & & & & \\
\hline DM & 279.71 & 290.40 & 286.90 & 265.90 & 268.70 & 0.40 & $y=290.0-0.07139840 x$ & 0.24 & 0.05 \\
\hline $\mathrm{NH}_{3}-\mathrm{N}$ & & 43.20 & 47.61 & 55.31 & 63.20 & 0.15 & $y=41.8+0.061932370 x$ & 0.62 & 0.0003 \\
\hline $\mathrm{pH}$ & & 3.35 & 3.72 & 3.87 & 3.90 & 0.03 & $\begin{array}{r}y=3.14+0.006517921 x- \\
0.000012319 x^{2}\end{array}$ & 0.90 & $<0.0001$ \\
\hline Lactic acid & & 19.50 & 34.20 & 38.25 & 33.03 & 0.12 & $\begin{array}{r}y=11.04+0.264381720 x \\
-0.000567170 x^{2}\end{array}$ & 0.69 & 0.0005 \\
\hline Acetic acid & & 15.70 & 18.43 & 18.71 & 11.30 & 0.32 & $\begin{array}{r}y=14.00+0.068991940 x \\
-0.000213430 x^{2}\end{array}$ & 0.54 & 0.006 \\
\hline Propionic acid & & 3.90 & 4.10 & 4.20 & 5.00 & 0.01 & $y=3.70+0.003188406 x$ & 0.45 & 0.004 \\
\hline Effluent & & 9.40 & 11.15 & 22.50 & 31.81 & 0.15 & $y=5.00+0.082487923 x$ & 0.89 & $<0.0001$ \\
\hline Gas loss & & 36.03 & 50.40 & 71.05 & 81.31 & 1.37 & $y=37.90+0.097739130 x$ & 0.43 & 0.005 \\
\hline DMR & & 964.07 & 946.61 & 929.01 & 918.7 & 1.50 & $y=959.30-0.15805310 x$ & 0.39 & 0.01 \\
\hline
\end{tabular}

DM: dry matter $(\mathrm{g} / \mathrm{kg}), \mathrm{NH}_{3}-\mathrm{N}$ : ammonia nitrogen ( $\mathrm{g} / \mathrm{kg}$ total nitrogen), $\mathrm{x}$ : time in storage

Despite the increase in ammonia- $\mathrm{N}$ concentrations observed in this study, these values did not affect silage quality. However, the increase in non-protein $\mathrm{N}$ values might affect the dynamics of silage degradation at rumen level, with a direct effect on the performance of formulated diets, because it difficult to synchronize the rate of carbohydrate and protein breakdown in microbial protein synthesis (Yang et al., 2010). In addition, it may increase the risks considerably of using urea in ruminant diets when the inclusion of silage is high.

Owing to its greater volume, lactate acid proved to be the most important acid produced in the silos. According to the statistical model, the accumulation of lactic acid increased until day 162 of fermentation, showing that a possible stabilization of the fermentation could last much longer than has been described (Gary, 1992; Pahlow et al., 2003; Kung Jr. et al., 2013). Likewise, the acetic acid accumulation curve was similar to that described for lactic acid, with peak accumulation at 233 days of fermentation. Acetate is the most oxidized fermentation product relative to glucose (Kozloski, 2017), which indicates that there are losses related to fermentation, especially by gases, during this period of greater acetic acid accumulation within the silo.

The increasing linear behaviour of losses as effluents $(P<0.05)$ and gases $(P>0.05)$ during storage is seen as a reflection of the fermentation process. Possibly, the fermentation side effects, which cause cell disruption and promote intracellular content extravasation to the external environment, could be attributed to the oxidation process of hexoses, which results in the production of organic acids, carbon gas, and water (Muck, 2010; Weinberg \& Chen, 2013). Also, the production of acetic acid and other volatile organic compounds by heterolactic bacteria during fermentation could increase DM losses (Kung et al., 2018). The concentration of propionic acid increased linearly with storage (Table 1). This can be explained by the reduction in acetic and lactic acids after its peak, as bacteria can use this acid in the acrylate route, producing propionate as a fermentation by-product (Kozloski, 2017). Under conditions of low concentration of soluble sugars, certain bacteria can use these acids from fermentation as energy sources, especially lactate (Lindgren et al., 1990).

Butyric acid levels did not fit the regression analysis $(P>0.05)$ with a mean value of $0.10 \%$ of DM. High levels of butyric acid indicated deterioration of the material. However, at concentrations below $0.10 \%$ DM, they did not compromise the nutritional quality of corn silage (McDonald et al., 1991). Bueno et al. 
(2020), who evaluated corn silage stored for 180 days, found no effect on the levels of butyric acid, corroborating the findings of the current study.

Ammonia-N and non-protein N (A fraction) concentrations increased linearly, whereas crude protein and soluble true protein (B1 and B2 fractions) decreased linearly with storage (Tables 1 and 2), because of the proteolysis, which causes hydrolysis of protein peptide bonds through the action of enzymes present in plant cells generating non-protein nitrogenous compounds such as ammonia, nitrates, nitrites, free amino acids, and peptides (McDonald et al., 1991). Because soluble $\mathrm{N}$ and ammonia- $\mathrm{N}$ are protein breakdown products, protein degradation generally increases over time. Ammonia- $\mathrm{N}$ is described in the literature as an exclusive protein deamination product. This was demonstrated in studies that evaluated storage periods in corn silages such as 240 days (Ferraretto et al., 2015) and 45 and 150 days of silo fermentation (Young et al., 2012), indicating that the proteolytic mechanisms were active during storage.

Table 2 Protein fractions predicted by the Cornell net carbohydrate and protein system for maize silage as functions of storage time

\begin{tabular}{|c|c|c|c|c|c|c|c|c|c|}
\hline \multirow{2}{*}{$\begin{array}{l}\text { Protein } \\
\text { fraction } \\
\text { (g/kg TN) }\end{array}$} & \multicolumn{5}{|c|}{ Storage time } & \multirow{2}{*}{ SE } & \multirow{2}{*}{ Equations } & \multirow{2}{*}{$\mathrm{R}^{2}$} & \multirow{2}{*}{$\begin{array}{c}P- \\
\text { value }\end{array}$} \\
\hline & $\begin{array}{c}\text { Pre- } \\
\text { ensiling }\end{array}$ & 45 & 90 & 180 & 360 & & & & \\
\hline $\mathrm{CP}$ & 85.10 & 87.60 & 83.00 & 84.20 & 82.21 & 0.11 & $y=87.0-0.014507250 x$ & 0.42 & 0.02 \\
\hline A & 349.30 & 477.30 & 552.83 & 618.05 & 631.60 & 1.90 & $y=482.7+0.4548000 x$ & 0.98 & 0.0006 \\
\hline B1 & 14.00 & 27.41 & 21.97 & 24.03 & 15.50 & 10.72 & $y=27.7-0.03241546 x$ & 0.62 & 0.01 \\
\hline B2 & 390.80 & 399.60 & 399.61 & 271.50 & 252.71 & 4.00 & $y=381.3-0.40806760 x$ & 0.97 & 0.0002 \\
\hline B3 & 127.20 & 60.50 & 60.53 & 40.60 & 56.47 & 77.80 & $\begin{array}{r}y=73.7-0.31408065 x+ \\
0.00073815 x^{2}\end{array}$ & 0.85 & 0.01 \\
\hline C & 118.80 & 34.91 & 34.97 & 45.70 & 43.63 & 84.01 & $y=4.27$ & 0.63 & 0.08 \\
\hline
\end{tabular}

TN: total nitrogen $=14.1-0.26000310 x$, CP: crude protein $(\mathrm{g} / \mathrm{kg} \mathrm{DM}), \mathrm{A}:$ non-protein nitrogen $(\mathrm{g} / \mathrm{kg} \mathrm{TN})$, B1: protein rapidly degradable in the rumen $(\mathrm{g} / \mathrm{kg} \mathrm{TN})$, B2: protein of intermediate rumen degradation rate $\left(\mathrm{g} \mathrm{kg}^{-1} \mathrm{TN}\right)$, B3: protein slowly degraded in the rumen ( $\mathrm{g} / \mathrm{kg} \mathrm{TN}), \mathrm{C}$ : insoluble and indigestible protein $(\mathrm{g} / \mathrm{kg} \mathrm{TN}), \mathrm{x}$ : time in storage

The CP content decreased as the silages were stored longer (Table 2). The fractions of true protein with greater solubility (B1 and B2 fractions) underwent intense proteolysis and decreased progressively with time in storage (Table 2). As a result, the non-protein $\mathrm{N}$ content (A fraction) increased with each additional day of storage. The increase in the A fraction mirrors the observed increase in ammonia-N. The B3 fraction presented a quadratic effect with a minimum value of $40.28 \mathrm{~g} / \mathrm{kg}-1$ total nitrogen at 213 days. No difference was found in the $C$ fraction, which is the protein associated with lignin (acid detergent insoluble $N$ ).

The A1 fraction of carbohydrates, which represents the accumulated gas volume (AGV) produced by fermentation, showed a quadratic behaviour with increasing storage (Table 3). The peak AGV occurred on the 167th day of fermentation, similar to the behaviour described in Table 1 for acetic acid and propionic acid. The A2 fraction, which represents lactic acid, also showed a quadratic behaviour, showing a high correlation $(r=0.87 ; P=0.0004)$ with lactic acid measured directly by means of gas chromatography. The A3 fraction was not detected in silages because organic acids other than lactic and acetic acids were almost undetectable in the silages. Soluble sugar content, corresponding to the A4 fraction, did not fit the regression model, with an average content of $29.11 \mathrm{~g} / \mathrm{kg} \mathrm{DM}$. The starch (B1) presented a quadratic effect, reaching its maximum value of $205.20 \mathrm{~g} / \mathrm{kg}$ at 167 days of storage, whereas the amount of soluble fibre (B2) decreased with increasing storage. There was a reduction in soluble fractions and a consequent increase in fibrous fractions (B3) as the storage period increased. The degradation of the B1 and B2 fractions over time adversely affects the nutritional value of the silage (Russell et al., 1992). The evaluation of fraction B2 is important because its degradation is related directly to passage rate, and the extent to which the protein is degraded in the rumen is important in determining the $\mathrm{N}$ supply to microorganisms (Carvalho et al., 2008).

The $\mathrm{A} 1$ and $\mathrm{A} 2$ carbohydrate fractions as determined by the Cornell Net Carbohydrate and Protein System (CNCPS) expressed behaviour similar to that observed for AGVs with greater participation in silages (lactate and acetate). The A2 fraction showed a high correlation with the lactic acid determined by gas chromatography.

According to the statistical model, the concentration of starch in the silages increased until day 167 of fermentation and then decreased, indicating a quadratic behaviour (Table 3 ). These results were not 
expected, and therefore their analyses were repeated without changes in methods. Two factors may be involved in this response, which often affect the fermentative parameters and nutritional value of silages at farm level, namely the type of grain and grain breakage. The hybrid had semi-toothed grains, which have a glassier endosperm than toothed grains. Also, when the silage was chopped, the grains remained intact. These factors could have prevented hydrolysis inside the grain, preventing microbial fermentation of starch, at least until the 167th day of storage. Thus, the concentration of starch increased owing to the use of other nutrients for fermentation. Hentz et al. (2017) observed an average content of $1.8 \mathrm{~g} / \mathrm{kg} \mathrm{DM}$ for fraction A4 in corn silage. However, Hall (2000) reported values from 3 to $47 \mathrm{~g} / \mathrm{kg}$ as the ideal range for the A4 fraction, and an average of $20 \mathrm{~g} / \mathrm{kg}$ DM in corn silage, which were consistent with the results obtained in this study.

Table 3 Total carbohydrate and non-fibrous carbohydrate fractions predicted by the Cornell net carbohydrate and protein system for maize silage as functions of storage time

\begin{tabular}{|c|c|c|c|c|c|c|c|c|c|}
\hline \multirow{2}{*}{$\begin{array}{l}\text { Fraction } \\
\text { (g/kg DM) }\end{array}$} & \multicolumn{5}{|c|}{ Storage time } & \multirow[b]{2}{*}{ SE } & \multirow[b]{2}{*}{ Equations } & \multirow[b]{2}{*}{$\mathrm{R}^{2}$} & \multirow[b]{2}{*}{$P$} \\
\hline & $\begin{array}{c}\text { Pre- } \\
\text { ensiling }\end{array}$ & 45 & 90 & 180 & 360 & & & & \\
\hline $\mathrm{CHO}$ & 837.35 & 834.15 & 845.12 & 829.15 & 834.25 & 4.14 & $y=835.66$ & & 0.52 \\
\hline NFC & 406.68 & 468.70 & 471.34 & 420.33 & 332.47 & 5.78 & $y=500.91-0.4604435 x$ & 0.97 & $<0.0001$ \\
\hline A1 & 0 & 20.85 & 23.68 & 24.15 & 17.40 & 0.95 & $y=19.00+0.07088710 x-$ & 0.79 & 0.02 \\
\hline A2 & 0 & 19.50 & 34.20 & 38.20 & 33.00 & 2.59 & $y=11.04+0.264381720 x-$ & 0.72 & 0.04 \\
\hline A4 & 91.97 & 28.63 & 32.41 & 25.41 & 30.00 & 1.90 & $y=29.11$ & & 0.38 \\
\hline B1 & 174.30 & 187.90 & 189.25 & 205.06 & 178.75 & 2.88 & $\begin{array}{r}y=173.88+0.3715523 x- \\
0.0011018 x^{2}\end{array}$ & 0.92 & 0.001 \\
\hline B2 & 170.43 & 211.83 & 198.80 & 118.34 & 63.36 & 7.77 & $y=216.36-0.3827720 x$ & 0.92 & 0.0002 \\
\hline B3 & 341.27 & 286.56 & 295.02 & 327.56 & 362.95 & 4.09 & $y=276.29+0.2473314 x$ & 0.94 & $<0.0001$ \\
\hline C & 89.39 & 78.85 & 78.76 & 81.24 & 138.83 & 3.27 & $y=61.07+0.19761932 x$ & 0.83 & 0.001 \\
\hline
\end{tabular}

$\mathrm{CHO}$ : total carbohydrates, NFC: non-fibrous carbohydrates, A1: sum of volatile fatty acids (acetic + propionic + butyric and isobutyric), A2: lactic acid, A4: soluble sugars, B1: starch, B2: soluble fibre, B3: digestible fibre, C: indigestible fibre, $\mathrm{x}$ : time in storage

Pectin (B2 fraction) was the most used nutrient for microbial fermentation after 45 days of fermentation, contributing to the increase in AGV concentration (above) with a linear decrease in its concentration as a function of storage period (Table 3). The reduction in the concentration of carbon nanofibres (CNFs) in the silages showed a high correlation $(r=0.87 ; P=0.0008)$ with the decrease in pectin values. Although they constitute the cell wall of plants, the fibrous particles (mainly leaves and stem) allowed hydrolysis and microbial fermentation, even if partial, of the primary cell wall, which was represented by the results (Sorieul et al., 2016).

Cellulose and hemicellulose (B3 fraction) and lignin (C fraction) increased with storage (Table 3), because they are less soluble and potentially less fermentable fractions of carbohydrates (Sniffen et al., 1992). Usually, the increase in these constituents restricts animal consumption because of the filling factor, reducing the animals' performance (Detmann et al., 2014). The increase in these constituents in silages occurs because of the fermentation of non-fibrous carbohydrate components, the soluble fraction, leading to the concentration of the silage fibrous fraction.

The final volume of the gas decreased as the duration increased (Figure 1 and Table 4). The largest volume of gas was produced from the original material. The differences AGV widened as time increased, which suggested that they were associated with slow fermentation carbohydrates. There was a higher concentration of structural carbohydrates (B3 fraction) in silages as they were stored for more time, whereas silages stored for less time had a higher concentration of non-fibrous carbohydrate (Table 2), because of the higher concentration of pectin (B2 fraction), which sustained the greater volume of gas. In addition, silages with longer storage showed greater proteolysis, with a greater amount of ammonia-N and non-protein N (A protein fraction), which possibly contributed to the lower volume of gas (Tables 1 and 2). 


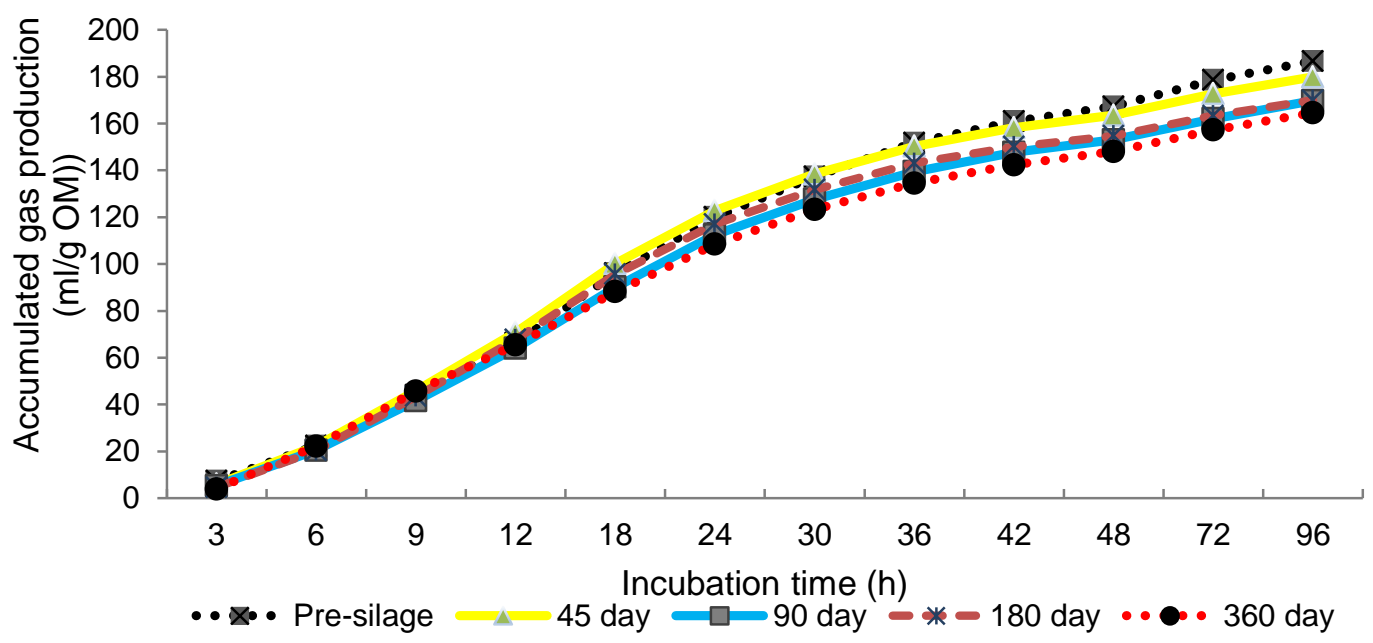

Figure 1 Cumulative gas production profiles for maize silage stored for different periods after ensiling from in vitro fermentation over 96 hours of incubation

The highest fermentation rate $\left(S=5.58 \mathrm{~h}^{-1}\right)$ was observed in the first 12 hours of incubation. However, duration did not affect gas production in vitro (Table 4). In the other incubation periods, especially 24 and 48 hours, the volume of gas produced increased as the duration decreased (Table 4). The greatest relative gas accumulation occurred in the first 24 hours of fermentation $(\approx 65 \%$ of the gas produced), with an average fermentation rate of $4.80 \mathrm{~h}^{-1}$, and almost all the silage was fermented within 48 hours $(\approx 90 \%)$ during in vitro incubation. In terms of dietary strategies, in vitro ruminal kinetics evaluations with higher incubation periods would not be necessary or recommended.

Table 4 Gas production as a function of incubation time and kinetic degradation of maize silage stored for various periods after ensiling

\begin{tabular}{|c|c|c|c|c|c|c|c|c|c|}
\hline \multirow{2}{*}{$\begin{array}{l}\text { Gas production, } \\
\mathrm{ml} / \mathrm{g}\end{array}$} & \multicolumn{5}{|c|}{ Storage time } & \multirow[b]{2}{*}{ SE } & \multirow{2}{*}{ Equations } & \multirow[b]{2}{*}{$\mathrm{R}^{2}$} & \multirow{2}{*}{$\begin{array}{c}P- \\
\text { value }\end{array}$} \\
\hline & $\begin{array}{c}\begin{array}{c}\text { Pre- } \\
\text { ensiling }\end{array} \\
\end{array}$ & 45 & 90 & 180 & 360 & & & & \\
\hline $\begin{array}{l}\text { Latency time, } \\
\text { hours }\end{array}$ & 2.02 & 2.25 & 2.14 & 2.39 & 1.33 & 1.01 & $y=2.03$ & & \\
\hline 12 hours & 66.35 & 70.78 & 64.01 & 67.81 & 65.48 & 2.66 & $y=67.02$ & & \\
\hline 24 hours & 120.02 & 122.78 & 112.46 & 117.13 & 108.43 & 2.55 & $y=120.72-0.033267 x$ & 0.42 & 0.0032 \\
\hline 48 hours & 167.24 & 163.52 & 152.99 & 154.75 & 148.02 & 2.73 & $y=162.90-0.044678 x$ & 0.55 & 0.0005 \\
\hline 96 hours & 186.65 & 179.85 & 169.73 & 169.89 & 164.62 & 2.85 & $y=179.95-0.047914 x$ & 0.69 & 0.0004 \\
\hline $\mathrm{s}$ & 3.13 & 3.53 & 3.32 & 3.62 & 3.20 & 0.95 & $y=3.38$ & & \\
\hline OMD & 404.06 & 409.66 & 389.66 & 402.12 & 381.66 & 5.07 & $y=406.60-0.064644 x$ & 0.42 & 0.0048 \\
\hline
\end{tabular}

S: fermentation rate per hour, latency time: colonization time (hours), OMD: organic matter digestibility (g/kg DM), x: time in storage

A higher fermentation rate was observed in the first 12 hours of incubation (Table 4) because of the fermentation of carbohydrates and highly soluble proteins in the rumen environment, the direct fermentation of pentose and hexoses, and indirectly the neutralization of AGVs by the bicarbonate buffer in the rumen liquid (Getachew et al., 1998).

The differences in the fractions of carbohydrates and proteins apparently complemented each other. On one hand, there was a quadratic increase in the starch content of the silages owing to the storage duration. Therefore, it was expected to increase the volume of gas produced in the first 12 hours of 
fermentation, with a ruminal degradation rate of $30 \%$ per hour, according to the CNCPS. On the other hand, these silages showed ammonia- $\mathrm{N}$, non-protein $\mathrm{N}$, and soluble protein (with a degradation rate of $315.25 \%$, according to the CNCPS), which may have reduced the volume of gas produced in that incubation period. The degradation of ammonia- $\mathrm{N}$ of the protein, related to $\mathrm{HCO}_{3}$, intensified the formation of ammonium carbonate, which precipitated in the solution and reduced the formation of $\mathrm{CO}_{2}$ (Russell et al., 1992).

After 96 hours of incubation (Figure 1) lower values of total gas production were observed for corn silage samples than for non-ensiled (pre-ensiled) samples, possibly because of fermentation losses during ensiling, as the control samples were not fermented, so there were no fermentation losses (McDonald et al., 1991). A higher gas volume was obtained from silages with shorter storage (24, 48, and 96 hours) (Figure 1 and Table 4), in agreement with Ali et al. (2014), who observed an inverse relationship between gas production and silage storage (up to 16 weeks). The higher volume of gas was sustained by the higher concentration of pectin in these silages (Table 3), which has a slower ruminal degradation than starch, contributing to fermentable material beyond the first 12 hours. Furthermore, silages with the longest storage had higher cellulose and hemicellulose content, which have a slow ruminal degradation rate of $5 \% / \mathrm{h}$ of the B3 fraction, and a higher indigestible fibre content ( $C$ fraction), which cannot be degraded in the ruminal environment because it is associated with lignin (Sniffen et al., 1992; Viana et al., 2012).

\section{Conclusions}

The longer silage is stored, the lower its quality, with greater losses of gases and effluents. In addition, silage with lower quality protein and nutritional value has a lower in vitro degradability.

Acknowledgements Coordenação de Aperfeiçoamento de Pessoal de Nível Superior (CAPES) and Conselho Nacional de Desenvolvimento Científico e Tecnológico (CNPq)

\section{Authors' Contributions}

SNP(conception and design of study; acquisition of data; analysis and/or interpretation of data and drafting the manuscript); JV (conception and design of study; acquisition of data; analysis and/or interpretation of data and drafting the manuscript); TJT (conception and design of study; acquisition of data; analysis and/or interpretation of data and drafting the manuscript), LLS (conception and design of study; acquisition of data; analysis and/or interpretation of data and drafting the manuscript), MBF (acquisition of data and analysis), LTR (acquisition of data and analysis), GRM (acquisition of data and analysis) and Roger Wagner (acquisition of data and analysis).

\section{Conflicts of Interest Declaration}

The authors declare no conflict of interest.

\section{References}

Ali, M., Van Duinkerken, G., Cone, J., Klop, A., Blok, M., Spek, J., Bruinenberg, M.H., Hendriks, W., 2014. Relationship between chemical composition and in situ rumen degradation characteristics of maize silages in dairy cows. Animal 8, 1832-1838.

Association of Official Analytical Chemists (AOAC), 1995. Official methods of analysis. 16th ed. AOAC International, Arlington.

American Oil Chemists Society (AOCS), 2005. Office Procedure, Approved Procedure Am 5-04. Rapid determination of oil/fat utilizing high temperature solvent extraction. AOCS, Urbana, IL.

Arcari, M.A., Martins, C.M.M.R., Tomazi, T. \& Santos, M.V., 2016. Effect of the ensiling time of hydrated ground corn on silage composition and in situ starch degradability. Braz. J. Vet. Res. An. Sci. 53, 60-71. DOI: 10.11606/issn.1678-4456.v53i1p60-71

Bueno, J.L., Bolson, D.C., Jacovaci, F.A., Gomes, A.L.M.,Ribeiro, M.G., Bueno, A.V., Jobim, C.C., Daniel, J.L.P., 2020. Storage length interacts with maturity to affect nutrient availability in unprocessed flint corn silage. R. Bras. Zootec. 49, 1-14. https://doi.org/10.37496/rbz4920190247

Carvalho, G.G.P.D., Garcia, R., Pires, A.J.V., Pereira, O.G., Fernandes, F.E.P., Cecon, P.R. \& Azevêdo, J.A.G., 2008. Fracionamento de proteínas de silagem de capim-elefante emurchecido ou com farelo de cacau. Ciênc. Anim. Bras. 9, 648-656.

Cornell Net Carbohydrate And Protein System (CNCPS) for evaluating herd nutrition and nutrient excretion, 2003. Version 5.0, Cornell University, Ithaca, New York.

Der Bedrosian, M.C., Nestor, K. \& Kung Jr. L., 2012. The effects of hybrid, maturity, and length of storage on the composition and nutritive value of corn silage. J. Dairy Sci. 95, 5115-5126. https://doi.org/10.3168/jds.2011-4833

Detmann, E., Gionbelli, M.P. \& Huhtanen, P., 2014. A meta-analytical evaluation of the regulation of voluntary intake in cattle fed tropical forage-based diets. J. Dairy Sci. 92, 4632-4641. DOI: 10.2527/jas.2014-7717

Ferraretto, L.F., Shaver, R.D., Massie, S., Singo, R., Taysom, D.M. \& Brouilette, J.P., 2015. Effect of ensiling time and hybrid type on fermentation profile, nitrogen fractions, and ruminal in vitro starch and neutral detergent fiber digestibility in whole-plant corn silage. Prof. Anim. Scient.. 31, 146-152. https://doi.org/10.15232/pas.2014-01371

Gary, M., 1992. Ensiling process. In: M. Bjorge \& H. Bjorge (eds). Silage manual. Alberta Agriculture and Rural Development, Edmonton, Alberta. 
Getachew, G., De Peters, E.J., Robinson, P.H., Fadel, J.G., 2005. Use of an in vitro rumen gas production technique to evaluate microbial fermentation of ruminant feeds and its impact on fermentation products. Anim. Feed Sci. Technol. 123, 547-559. https://doi.org/10.1016/j.anifeedsci.2005.04.034

Hall, M.B., 2000. Neutral detergent-soluble carbohydrates, nutritional relevance and analysis. A laboratory manual. Bulletin 339. University of Florida, Florida.

Hentz, F., Velho, J.P., Nörnberg, J.L., Harygert-Velho, I.M.P., Henz, E.L., Henn, J.D. \& Zardin, P.B., 2017. Fractionation of carbohydrates and nitrogenous constituents of late-crop corn silages ensiled with different specific masses. Semina: Cienc. Agr. 38, 491-502. DOI: 10.5433/1679-0359.2017v38n1p491

Hoffman, P.C., Esser, N.M., Shaser, R.D., Coblentz, W.K., Scott, M.P., Bodnar, A.L., Schmidt, R.J. \& Charley, R.C., 2011. Influence of ensiling time and inoculation on alteration of the starch-protein matrix in high-moisture corn. J. Dairy Sci. 94, 465-2474. DOI: 10.3168/jds.2010-3562

Köppen, W. \& Geiger, R., 1928. Klimate der Erde. Verlag Justus Perthes, Gotha. Wallmap $150 \mathrm{~cm} \times 200 \mathrm{~cm}$.

Kozloski, G.V., 2017. Bioquímica dos ruminantes. 2nd ed. Universidade federal de Santa Maria (UFSM), Santa Maria, RS.

Kung Jr., L., 2013. The effects of length of storage on the nutritive value and aerobic stability of silages. In: International Symposium on Forage Quality and Conservation, Campinas, Brazil. http://www.isfqcbrazil.com.br/proceedings/2013/proceedings-of-the-iii-international-symposium-of-fprage-qualityand-conservation-51.pdf

Kung Jr., L., Shaver, R.D., Grant, R.J. \& Schmidt, R.J., 2018. Silage review: Interpretation of chemical, microbial, and organoleptic components of silages. J. Dairy Sci. 101, 4020-4033. https://doi.org/10.3168/jds.2017-13909

Lanzas, C., Tedeschi, L.O., Seo, S. \& Fox, D.G., 2007. A revised CNCPS feed carbohydrate fractionation scheme for formulating rations for ruminants. Anim. Feed Sci. Technol. 136, 167-190. https://doi.org/10.1016/j.anifeedsci.2006.08.025

Li, M., Zi, X., Zhou, H., Hou, G., Cai, Y., 2014. Effects of sucrose, glucose, molasses and cellulase on fermentation quality and in vitro gas production of king grass silage. Anim. Feed Sci. Technol. 197, $206-2012$. https://doi.org/10.1016/j.anifeedsci.2014.06.016

Licitra, G., Hernandez, T.M. \& Van Soest, P.J., 1996. Standardization of procedures for nitrogen fractionation of ruminant feeds. Anim. Feed Sci. Technol. 57, 347-358. https://doi.org/10.1016/0377-8401(95)00837-3

Lindgren, S.E., Axelsson, L.T., Mcfeeters, R.F., 1990. Anaerobic L-lactate degradation by Lactobacillus plantarum. FEMS Microbiology Letters 66, 209-214. https://doi.org/10.1016/0378-1097(90)90284-W

López, S., Dhanoa, M.S., Dijkstra, J., Bannink, A., Kebreab \& E., France, J., 2007. Some methodological and analytical considerations regarding application of the gas production technique. Anim. Feed Sci. Technol. 135, 139-156. https://doi.org/10.1016/j.anifeedsci.2006.06.005

McDonald, P., Henderson, A.R. \& Heron, S.J.E., 1991. The biochemistry of silage. 2nd ed. Chalcombe, United Kingdom.

Menke, B.K.H., Raab, L., Salewski, A., Steingass, H., Fritz, D. \& Schneider, W., 1979. The estimation of the digestibility and metabolizable energy content of ruminant feeding stuffs from the gas production when they are incubated with rumen liquor in vitro. J. Agric. Sci. 93, 217-222. DOI: 10.1017/S0021859600086305

Muck, R.E., 2010. Silage microbiology and its control through additives. R. Bras. Zootec. 39, $183-191$. DOI:10.1590/S1516-35982010001300021

Naeini, S.Z., Emani, N.K., Rowhani. E. \& Bayat, A., 2014. Influence of ensiling time on chemical composition, fermentation characteristics, gas production and protein fractions of sweet sorghum silage. Res. Opi. Anim. Vet. Sci. 4, 286-293.

Oms-Oliu, G., Hertog, M.L.A.T.M., Van de Poel, B., Ampofo-Asiama, J., Geeraerd, A.H. \& Nicolai, B.M., 2011. Metabolic characterization of tomato fruit during preharvest development, ripening, and postharvest shelf-life. Posthar. Biol. Technol. 62, 7-16. DOI: 10.1016/j.postharvbio.2011.04.010

Pahlow, G., Muck, R.E. \& Driehuis, F., 2003. Microbiology of ensiling. In: D.R. Buxton, R.E. Muck \& J.H. Harrison (eds). Silage Science and Technology. American Society of Agronomy. Madison, WI, Pp. 31-93

Playne, M.J. \& McDonald, P., 1966. The buffering constituents of herbage and of silage. J. Sci. Food. Agric. 17, $264-268$. DOI: 10.1002/JSFA.2740170609

Rede Oficial de Laboratórios de Análise de Solo e de Tecido Vegetal (Rolas), 2006. Manual de adubação e calagem para os estados do Rio Grande do Sul e Santa Catarina. 10th edition. Sociedade Brasileira de Ciência do Solo.

Russell, J.B., O'Connor, J.D., Fox, D.G., Van Soest, P.J. \& Sniffen, C.J., 1992. A net carbohydrate and protein system for evaluation cattle diets: Ruminal fermentation. J. Anim. Sci. 170, 3551-3581. https://doi.org/10.2527/1992.70113562x

Schofield, P., Pitt, R.E. \& Pell, A.N., 1994. Kinetics of fiber digestion from in vitro gas production. J. Anim. Sci. 72, 29802991. https://doi.org/10.2527/1994.72112980x https://www.researchgate.net/publication/15469382_Kinetics_of_fiber_digestion_from_in_vitro_gas_production

Senger, C.C.D., Kozloski, G.V., Sanchez, L.M.B., Mesquita, F.R., Alves, T.P. \& Castagnino, D.S., 2008. Short communication: Evaluation of autoclave procedures for fibre analysis in forage and concentrate feedstuffs. Anim. Feed Sci. Technol. 146, 169-174. https://doi.org/10.1016/j.anifeedsci.2007.12.008

Silva, D.J. \& Queiroz, A.C., 2002. Análise de alimentos: Métodos químicos e biológicos. Editora Universidade Federal de Viçosa- UFV. Minas Gerais. 3rd ed.

Sistema Brasileiro de Classificação de Solos (Embrapa-CNPS)., 2006. Embrapa- Produção de informação, 412 pp.

Sniffen, C.J., O'Connor, J., Van Soest, P.J., Fox, D.J. \& Russell, J.B., 1992. A net carbohydrate and protein system for evaluating cattle diets: Carbohydrate and protein availability. J. Anim. Sci. 70, 3562-3577. DOI: $10.2527 / 1992.70113562 x$ 
Sorieul, M., Dickson, A.J., Hill, S. \& Pearson, H., 2016. Plant fibre: Molecular structure and biomechanical properties of a complex living material, influencing its deconstruction towards a biobased composite. Materials-MDPI 9, 1-36. https://doi.org/10.3390/ma9080618

Tangerman, A. \& Nagengast, F.M.A., 1996. Gas chromatographic analysis of fecal short-chain fatty acids, using the direct injection method. Anal. Biochem. 236, 1-8. DOI:10.1006/abio.1996.0123

Theodorou, M.K., Williams, B.A., Dhanoa, M.S., McAllen, A.B. \& France, J., 1994. A simple gas production using a pressure transducer to determine the fermentation kinetics of ruminant feeds. Anim. Feed Sci. Technol. 48, 185197. https://doi.org/10.1016/0377-8401(94)90171-6

Walter, M., Silva, L.P. \& Perdomo, D.M.X., 2005. Amido disponível e resistente em alimentos: adaptação do método da AOAC 996.11. Alimentos e Nutrição 16, 39-43.

Weatherburn, M.W., 1967. Phenol-hypochlorite reaction for determination of ammonia. Anal Chem. 39, 971-974. https://doi.org/10.1021/ac60252a045

Weinberg, Z.G. \& Chen, Y., 2013. Effects of storage period on the composition of whole crop wheat and corn silages. Anim. Feed Sci. Technol. 185, 196-200. http://dx.doi.org/10.1016/j.anifeedsci.2013.08.009

Van Soest, P.J., Robertson, J.B. \& Lewis, B.A., 1991. Methods for dietary fiber, neutral detergent fiber, and nonstarch polysaccharide in relation to animal nutrition. J. Dairy Sci. 74, 3583-3597. DOI: 10.3168/jds.S00220302(91)78551-2

Viana, T.V., Pires, A.J.V., Oliveira, L.B., Carvalho, G.G.P., Ribeiro, L.S.O., Chagas, D.M.T., Filho, C.S.N. \& Carvalho, A.O., 2012. Fracionamento de carboidratos e de proteína das silagens de diferentes forrageiras. R. Bras. Zootec. 41, 292-297.

Yang, J.Y., Seo, J., Kim, H.J., Seo, S. \& Jong, K.H., 2010. Nutrient synchrony: Is it a suitable strategy to improve nitrogen utilization and animal performance? Asian-Australasian J. Anim. Sci. 23, 972-979. DOI: 10.5713/ajas.2010.r.04

Young, K.M., Lim, J.M. \& Der Bedrosian, M.C. \& Kung, Jr. L., 2012. Effect of exogenous protease enzymes on the fermentation on nutritive value of corn silage. J. Dairy Sci. 95, 6687-6694. http://dx.doi.org/10.3168/jds.2012-562 